\title{
Popular participation and Previous County Health Conference
}

\author{
Participação popular e Pré-Conferência Municipal de Saúde \\ Participación popular y Pre-Conferencia Municipal de Salud
}

\author{
Luís Carlos Lopes-Júnior ${ }^{1}$, Maria José Bistafa Pereira ${ }^{1}$, Silvana Martins Mishima ${ }^{1}$
}

The article aimed at reporting the participation of a post graduate nursing student in the core of a previous county health conference. This is an experience, descriptive and reflective report, held in Ribeirão Preto, São Paulo, Brazil, in the first semester of 2011. The Pre-Conference has resulted in the compilation of 50 proposals that involved the following areas: access to actions and health services; work management and health education; community participation; social security system; access and quality of reception. The Pre-Conference revealed the increasing plurality of society and its interests, and the distance between the managers on one hand, and on the other the organs of social participation.

Descriptors: Social Participation; Consumer Participation; Health Councils; Health Policy.

0 artigo teve como objetivo relatar a experiência da participação de um enfermeiro pós-graduando no bojo de uma PréConferência Municipal de Saúde. Trata-se de um relato de experiência, de cunho descritivo-reflexivo, realizado no município de Ribeirão Preto, estado de São Paulo, Brasil, no primeiro semestre de 2011. A Pré-Conferência resultou na compilação de 50 propostas que versavam sobre os seguintes eixos temáticos: acesso a ações e serviços de saúde; gestão do trabalho e educação em saúde; participação da comunidade; sistema de seguridade social; acesso e acolhimento com qualidade. A PréConferência revelou ao mesmo tempo a pluralidade crescente da sociedade e dos interesses nela presentes, e o afastamento entre os gestores de um lado e os órgãos de participação social de outro.

Descritores: Participação Social; Participação Comunitária; Conselhos de Saúde; Política de Saúde.

El objetivo fue relatar la participación de un enfermero de postgrado en el núcleo de una Pré-Conferencia Municipal de Salud. Relato de experiencia, descriptivo y reflexivo, llevado a cabo en la ciudad de Ribeirão Preto, estado de São Paulo, Brasil, en el primer semestre de 2011. La Pre-Conferencia se ha traducido en la elaboración de 50 propuestas acerca de los siguientes ejes temáticos: acceso a las acciones y servicios de salud; gestión de trabajo y educación en salud; participación comunitaria; sistema de seguridad social; acceso y acogimiento con calidad. La Pre-Conferencia reveló el creciente pluralismo de la sociedad y de los intereses, y la separación entre los gestores por un lado, y por otro, los órganos de participación social.

Descriptores: Participación Social; Participación Comunitaria; Consejos de Salud; Política de Salud.

\footnotetext{
${ }^{1}$ Escola de Enfermagem de Ribeirão Preto, Universidade de São Paulo. Ribeirão Preto, SP, Brazil. 


\section{Introduction}

Several societies and countries present a distribution in a wide scope of degrees of organized participation, of social consciousness and their relation with the State. In the Brazilian domain, the values, the consciousness of rights and the popular participation were widely debated in the core of society, a result of the movement of democratization of the country from the second half of the $80 \mathrm{~s}$ on, including the movement of the Brazilian Health Reform and more intensely during the end of the 80s decade going thought the VIII National Conference of Health in the National Constituent Assembly. In this context the Sistema Único de Saúde (The Unified Health System) started as powerful public policy which aims at the organized participation of the society ${ }^{(1-2)}$.

The Federal Constitution of 1988 represents a historical landmark in terms of recognition of several rights in Brazil. In its $6^{\text {th }}$ article, it stablishes 'the education, the health, the work, the leisure, the security, the social security, the protection to motherhood, the assistance to the helpless population' as social rights of the Brazilian people. Later on, in its $196^{\text {th }}$ article, it stablishes 'health as a right of everyone and the duty of the State, granted through social and economic policies and equal and universal access to

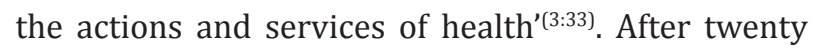
years since it was promulgated, it is undeniable the expansion of access to those rights ${ }^{(1)}$. However the universal right to health is well stablished from the Brazilian legislation point of view, but between these statements of purposes and reality, there are abysses which are almost unbridgeable.

The participation, understood as inherent to the social nature of man, is the way through which he shows his innate tendency of performing, doing things, confirming with himself and dominating the environment in which he is formed and at the same time constitutes him $^{(4)}$. Nevertheless his practice involves the satisfaction of other needs, such as self-expression, the interaction with other subjects, the development of a critical reflexive thought, the pleasure to create and recreate things, besides the valuing of oneself by the others ${ }^{(4)}$. Furthermore, the participation is a collective experience, not individual, so one can only learn through the exercise of the group relations. According to that, the frustration of the need to participate constitutes a mutilation of man. The greatest sense of participation is not when one takes part but actually how he takes part in this process ${ }^{(4)}$. Through his participation the subject appropriates and learns the possibilities of transforming the State, from a superimposed organ and distant from society, into a strictly dependent organ and close to it $^{(4)}$.

After two decades of the institutionalization of the Unified Health System, a movement of great social and constitutional conquest regarding the popular participation in the domain of health is noticed, once the participative character of the management of the system was a process built in decades of struggles, with advancement and regression in a permanent movement of construction ${ }^{(4)}$. When reflecting the degrees of mobilization and consciousness of the rights attained by society in the 80 s, the consecration of the participation in the community was highlighted. When regulating constitutional devices on the unified health system and the Organic Law of Health no. $8,080 / 1990$, which stablishes the conditions for the promotion protection and recuperation of health, in its $7^{\text {th }}$ article, it makes references to the participation of the community as a principle of the unified health system and law no. 8,142/1990, when regulating this practice, it institutes the Health Conferences and the Health Counsels ${ }^{(1)}$.

The Counsels are permanent instances of a deliberative character which exist in all the domains of the government and are mechanisms of social control and approval of the budget, with the attributions to act in the formulation of health strategies through the control of the practice of polices and through the analyses of the plans, programs and reports of management, submitted to their appreciation by the respective governmental levels ${ }^{(5)}$. Brazil currently has 
a National Counsel, 27 State Counsels and more than 5,500 County Health Counsels, covering almost all the Brazilians counties, employing around 72 thousand board members counsels, among them approximately 36 thousand represent the users of the public health ${ }^{(6)}$. All the counsels are made up by representatives of users (corresponding to $50 \%$ ), of workers of the health area (25\%), of the managers and providers of health services $(25 \%)^{(5)}$.

The conferences of propositional character are called following a periodicity of four years, to discuss varied subjects and transmit the different interests which end up formulating polices ${ }^{(5)}$. Each one of the conferences has an expressive number of representatives, with the same proportional distribution of the Counsels and it is aimed at analyzing the situations of health and stablishes guidelines which must orientate the whole process of health policies in the following period, thus contributing to the inclusion of important matters in the public $\operatorname{agenda}^{(5,7)}$.

Conferences and Health Counsels are within space stablished in the legal landmark for the social participation on the implementation of the health policy in all the domains of the government ${ }^{(5)}$. Although it existence goes back to the thirties of the $20^{\text {th }}$ Century, it is only after the Constitution of 1988 that they assumed the public character, which they present today and have been expressing themselves to the domains of the federal states and county governments ${ }^{(1)}$. In the previous period, the conferences were venues of intergovernmental articulation, with the participation being restricted to managers, technicians and specialists invited by the Secretaries of the State ${ }^{(1,5)}$. It should be highlighted that there are unique differences in the dynamics of the debates, and in the degree of generalization of the recommendations of the conferences in each one of the levels of management of the system. In this process the advances are significant, even if it is possible to identify the permanence of many frailties and the need of overcoming the corporative practices or the ones from the clientele which remain in many contexts $^{(1)}$.

Participating in the decision-making process and exercising control on the implementation of public policies are fundamental practices to enhance the possibility of concurring new social rights, and to depend on those conquests, also to minimize the inequalities and iniquities still rooted in the Brazilian society.

One of the characteristics which provides the unified health system an international and notorious singularity, is that in Brazil, the population has a seat in the highest stages of appeal of taking decisions regarding health, in the debate on the formulation, execution and evaluation of the national policy of health and that is why the denomination "social control" was given to the popular participation of the society in the Unified Health System ${ }^{(5)}$. The expression "social control" designates the set of actions of surveillance on the exercise of the rights of citizenship, referring to the different domains which might interfere on them: the State, the organization of several society and the institutions of private domain $^{(1)}$. In the Brazilian context, its concept became considered as the possibility of enhancing citizenship, specially related to the construction of democracy ${ }^{(8)}$. The participation as demagogy or as pedagogy gives place to the participation as citizenship, based on the universalization of the social rights and in the enhancing of the concept of citizenship itself, also making reference to a new comprehension of the character and the role of the State ${ }^{(6,8)}$.

This peculiar characteristic of the Counsels and the Health Conferences, which evoked the reflection on the participation of a post-graduated nurse in the core of a Pre-Conference of health presented as follows. It is expected that this article promotes a prominent debate and reflects the engagements of the several actors involved in participation in the community and reaffirms the pertinence of the articulation of the schooling - work - community nexus, in consonance with the principles of the Unified Health System. 
In this context the present study is aimed at reporting the experience of the participation of a post-graduate nurse in public health in the scope of a Previous County Health Conference.

\section{Method}

It is a descriptive reflective report of experience. The period of such experience was in the first semester of 2011.

The scenario of the study corresponds to the county of Ribeirão Preto, located in countryside of the state of São Paulo, Brazil, $317 \mathrm{~km}$ northwest of the state capital with a population of 605,114 inhabitants which classifies it as the $8^{\text {th }}$ most populous county in the state. Regarding the net of primary attention to health, Ribeirão Preto, had 47 units of basic attention at the time, distributed in five districts of health, of which five were county basic units of health, 13 were units of family health with a total of 21 teams of the Family Health Strategy; and 21 traditional basic units with 26 teams of Communitarian Agents of Health. The estimated population coverage in March, 2009 for the teams of a Family Health Strategy was $11.0 \%$ and the total population coverage for the teams of Communitarian Agents of Health was $32.1 \%$. The county manager recognizes the need to prioritize basic attention, placing it as a focus of investment and with technical and political legitimacy; pointing guidelines and strategies for the strengthening of the same in the county, according to what was predicted in the dimension Pact for Life of the Pact for Health stablished by Administrative Rule GM 699/2006 ${ }^{(9)}$.

At the time, Ribeirão Preto had a County Health Counsel formed by 26 members and their respective substitutes, being 13 representatives of the government of the service providers of health service and professionals and workers of health and the remaining 13 were representatives of the users. The existence of a County Health Counsel is the formal guaranty of the participation of the institutionalized community in the organization, management, inspection and control of the unified. The term of the Counsel coincides with the term of the mayor. The social participation in the Unified Health System is still formally performed at the health unit through the local committees of health being the main obstacle to the formation of the committee itself, thus indicating a process still incipient at this point ${ }^{(9)}$.

\section{Results}

\section{Presentation of the experience}

The Previous Health Conference, in the above mentioned county, has been a venue aiming at a broader coverage of publicizing of the County Conference, besides other purposes such as stimulating the involvement and participation of the population, pointing out the health problems and raising primary data for the elaboration of guidelines of the health policy. Besides that, it works as a place to choose the delegates who will represent the population at the County Conference. It has, as main focus, the promotion of a means where the community can share and contribute in the evaluation of the situation of the local health and elaborate proposals which will culminate in the County Health Conference. It also aims at making visible the transformation of the reality of these policies in the scope of the county and creates a political culture for the social participation in other levels (at the State Health Conference, National Health Conference), so it is a democratic venue for all and for all of those who participate ${ }^{(9)}$.

In the year 2011, Ribeirão Preto was having the $8^{\text {th }}$ edition of the County Health Conference, made in the middle of the year and which presented as theme, the one instituted by the National Health Counsel: 'Everyone uses the Unified Health System! The Unified Health System in the social security, public policies, assets of the Brazilian people'. In order to subsidize and preceding the $8^{\text {th }}$ County Conference the PreConference were organized, systematized and made in May and June, 2011 in the five health districts of 
Ribeirão Preto, as follows: Western, Northern, Eastern, Southern and Central Districts ${ }^{(9)}$.

Concerning the objective of this report of experience the look focuses on the Pre-Conference of the Western District, which provided an opening of trajectory of this big event. Around 70 people participated in the first of five Previous Health Conferences. The meeting which was turned to provide assistance to the western region of Ribeirão Preto, resulted in the compilation of 50 proposals, later on presented in the County Health Conference in July, 2011.

The opening plenary session of this PreConference was made up by the County Health Secretary, the Coordinator of Basic Attention to Health, the Manager of the Western District Unit, a Representative of the Social Assistance Department and a Representative of the County Health Counsel. However the mayor of the city was not present. The County Health Department had a primordial role, once they presented their point of view in the initial discussions, as well as leading the presented proposals to be integrated to the themes discussed at the County Conference. It is highlighted that the authors of that study were not direct representatives of any of the instances above mentioned.

The first moment of the event was a Conference called 'Health Policies, Health and Social Security' produced by members of the County Health Counsel and it was used as a trigger for the discussion in the Pre-Conferences. The text was very providential and it was able to generate a discussion among the present parties. This presentation brought to light the Unified Health System as a great asset ruled by a constitution which ensures the right to health, rooted by the process of social participation and the participation in the community which guides the construction and transformation of current health policies. It also evoked the discussion of the current concept of health, as political dimension (multiple social actors), economic (Health and market), religious, scientific and social protection (social rights) dimensions.
Health was emphatically highlighted as ethos of all the policies, that is, idealization of all the policies having health as their core. This moment of exposition of the conference was the 'climax' once it allowed a debate with several actors of the society who were present, speaking up their points of view. The matter of the fundamental education (basis), was approached by one the participants which is weakened in the county and which reflects the conformation of the Brazilian education; the focusing policies such as the Family Fund which seems not to promote the autonomy in the way of living of the benefited families. The process of preparation of the parents in the scope of the education was also called to reflection.

Another very well listed point by the County Counsellor which represented the residents' association was on the participation of the graduation and post-graduation students of the universities in the scenario of social participation in the Unified Health System. How do these actors, who are inserted in the Unified Health System and used for their education, provide the feedback for the system? Actually, it can be noticed that a minority of students were present at plenary sessions. Once again the education opposing the legacy of the Unified Health System was also observed. Maybe the Key point of this Pre-Conference was cleared by a representative of the Health Local Committee, which pointed the each time clearer need of the integration of the several departments (Social Assistance, Education, Infrastructure, etc.), That is, These several instances should start a dialogue, in a model of shared management, aware to listen to the needs of the population, aiming at the inter-sectorial articulation to comply with the complex integrity of care in the Unified Health System.

As the closing of the exposition a section of the following chap-book was presented 'The day the Unified Health System visited the citizen', in a poem version 'The day the citizen visited the Unified Health System' written by the conference speaker brought an interface of the social participation sensitizing the plenary to the reflection of the Unified Health System 
really existing and the one which is actually aimed at.

In the second moment of the Pre-Conference, the enrollments for the delegates who would be elected for the $8^{\text {th }}$ County Health Conference was oriented. The agreed criteria for the distribution of the seats in the Pre-Conferences and investiture for the several representations were the following: the seats of users without institutional representation, the seats of representatives of residents' associations and the Local Health Committees and the seats of civil servants and managers, were distributed according to the population proportion of each district; and the only inhabitants which were considered candidates were the ones older than 18 years of age and living in the geographic area of the health district for the user.

Soon after this explanation, the third moment of the event took place in which the participating audience was divided into three groups and each one elaborated around 15 proposals to be directed for approval at the County Conference. The first two moments occurred in an organized and systematized way, considering that the time allotted for these moments was favorable and convenient for discussions and reflections, which were marked by intense popular participation. However it was observed that the third moment, in small groups, did not have its purpose totally reached, once although there was participation, it was not possible to deepen the debates raised from the elaboration of the proposals.

In the small group that I managed to gather, there were 23 subjects among health professionals of the minimum team of the Family Health Strategy (doctors, nurses, nursing assistants, communitarian health agents, psychologists, physiotherapists, a few users of the community, students of graduation and post-graduation). So that we could work collectively in order to elaborate the proposals, the themes which were presented to us were around five axes: a) access to action and health services; b) management of work and education in health; c) participation of the community; d) system of social security; e) access and reception with quality: a challenge for the Unified
Health System.

Among these themes 14 proposals were jointly elaborated : 1) Rescue the law project of the County Health Counsel in order to restructure the law of regulation of the County Health Counsel of Ribeirão Preto, no.5,782 of 1991, having three months to be taken to the City Counsel; 2) Provide publicizing, valuing the recognition of the work of the teams of Health Communitarian Agents through a wider insertion of those agents in the team meetings, team work, promoting more dialogues among the health professionals; 3) Perform and reevaluation of the matter of the insalubrity of the Health Communitarian Agents; 4) Strengthen the Family Health Strategy enhancing the number of units in the county, teams of Nucleus of Support to Family Health, as well as providing the opening of a public exam for Health Communitarian Agents, within six months at the most; 5) Enhance the coverage of Family Health Strategy transforming the Program of Health Communitarian Agents into teams of Family Health Strategy, in order to enhance the coverage in $50 \%$ in a period of two years; 6) Create the plan of carrier, posts and salaries for the health county civil servants.; 7) Make a survey and population redistribution per health unit and equip and enhance the assistance of the Health Basic Units; 8) Use venues of the health units to work with education in health together with the population; 9) Propose to bring back the Program of Continued Education and Program of Permanent Education for the health professionals; 10)Implement a program of periodical evaluation of the health of the civil servant; 11) Reform the statute of the civil servant; 12) Recommend the Health County Counsel to organize an agenda to implement the local committees of health in the units of Western District within six months at the most; 13) Stablish security in the health units; 14) Elaborate a forum of the different County Departments with the presence of the mayor to identify the interfaces and propose joint and coordinated actions to overcome any obstacles of the care in health.

The time stipulated for this task was much 
shorter than the necessary time for discussion and reflection of the proposals put forward. At times, a few leaders confronted each other trying to lead the discussion to a path which did not consider some other points of view of their peers present, going away from the proposal of the Pre-Conference. The last proposals went through a restrict and superficial discussion and there was an absence of the subjects involved in the process, once the time was reduced as it had already been pointed out.

\section{Discussion}

Brazil has been under the egis of the Federal Constitution of 1988 for more than twenty years. And an intense social participation was the master key of the Unified Health System since its origin, with the articulation of the social movements in the years 1970 and 1980, culminating in the reform of the health sector ${ }^{(10-11)}$. Health emerged as a citizenship matter from the Health Unified System, and the political participation as the condition for its exercise. The establishment of Health Counsels undoubtedly represented an innovation ${ }^{(12-13)}$.

Until the $7^{\text {th }}$ Conference in 1980, only managers, some technicians and specialists invited, participated in the discussions concerning health policy in these forums. The $8^{\text {th }}$ Conference represented a watershed, despite the representation of users being still small: labor unions, residents' association. Especially after the $9^{\text {th }}$ National Health Conference there was a big expansion of the process of the participation. The implementation of Health Counsels and the making of Conferences in a growing number of counties resulted in intense mobilization, enhancing the range of actors involved and an increase in the heterogeneity of interests ${ }^{(13)}$. Nevertheless, the World Health Organization in their report of 2008 on the world health highlights the Brazilian experience of Health Conferences among the examples of advances in the construction of participative decision making processes $^{(14)}$.
The $8^{\text {th }}$ Conference had a fundamental role in the formulation of the Health Unified System and the construction of the national consciousness on the right to health. The subsequent ones also represented conquests in specific themes for the health sector. However, it has been noticed that the format of these Conferences must be revised and even debated, aiming at the construction of alternative forms with characteristics which can allow the expression of the concrete interests of the society and still assure the perspective to enhance their democratic character. New hopes arise when the National Counsel of Secretaries of Health calls the attention for the need to promote reflection on the distance among managers, Conferences and Health Counsels, a position which was manifested in a document of this entity.

It is highlighted that the effectiveness of the Counsels has been conditioned by several factors, which goes from the capacitation of the formulation and negotiation of proposals to the degree of autonomy of the subjects who formed them. It was observed that the responsibilities were not concentrated and there was no democratization of the power ${ }^{(15)}$.

The way our Conferences have been represented by the actors of the society should be a reflection. Besides that, we must also rethink the way through which the counselors who are diligent and committed to the Health Unified System, are being left behind in the representativeness at the moment of choosing delegates for the State and National Conferences. For such, it is extremely important to know and understand the Health Plans in their governmental instances: county, state and national thus empowering themselves in this process of participation and democratization.

The participation is an instrument of control of the State by society and it is presented as a potentiality of the citizens to be authors of the criteria and parameters related to the decisions in the scope of public policies ${ }^{(2)}$. Under this perspective, the citizens can be responsible for the conquest of new rights and to promote the decrease of the inequalities and 
iniquities so present in the Brazilian society.

The partial results of the research of Monitoring and Support to the Participative Management of the Unified Health System, has been used since 2003, by the Department of Strategic and Participative Management of the Health Department, it was important to stablish a landmark for this theme, once it is focused on the degree of the democratization of the County and States Counsels of Health in Brazil. This research which worked at first with the University 4,861 County Health Counsels and 27 State Health Counsels revealed a degree of democratization of the counsel bellow the expected results ${ }^{(12)}$. The legitimacy of the technical scientific argument within the counsels has the tendency to impose silence to popular experiences and to disallow the positioning of their representatives ${ }^{(12)}$.

The scientific literature reports that one of the most frequent and difficult problems to be overcome and solved are the matters concerning the composition, the representation and the representative of the counselors. In many counties it is observed that, besides not complying with the principal of the parity, the criteria are at times, obscure and strongly influenced by political interferences, especially in the determination of those who represent the interests of the users, who end up not truly representing the interests of the common citizens ${ }^{(16)}$.

The Health Counsels do not need more rules, legal power or institutional acts, but more policies, verbalization and visibility. It is necessary that there are citizens who are aware of their rights and duties in the process of construction of the Unified Health System, that is, with a reflexive and critical consciousness to play the role which is given them by right. The existence of an open State is also fundamental to experiment and validate the efficiency of this democratic process of co-management of the system $^{(17) .}$.

The construction of citizenship implies in the creation of rules, consensus and values shared both by the political elite as well as by the other members of the society ${ }^{(7)}$. It should be added that to have a true popular participation it is necessary to have the active and curious presence of subjects in the construction, admiration and re-admiration of the world, responsible for their own destiny and able to bring problems to the environment in which they live $\mathrm{e}^{(4)}$.

Parallel to that, the true acting of the Health County Counsel is questioned as a democratic public venue. Is it possible that democracy occurs only to supply a legal requirement and not to guarantee the right of inclusion of the citizen in the decisive process in health? Or is it the lack of knowledge of all the social actors involved in this process of social participation in health which was responsible for this reality?

One of the possibilities to change this reality would be the capacitation and permanent edification of the counselors, understood as practice for the empowerment and their liberation in a process of continuous and participative construction.

Another point that should be highlighted and rescued is concerning the existing education in Brazil, in which practically there is no register on the relevance of the schooling - service - management social control integration and the articulation with the courses of graduation of the health professionals ${ }^{(18)}$. From then on, the concept of the education quadrangle: teaching - management - attention and social control appeared in 2003, demonstrating an image for the area of health aimed at constructing and organizing a responsible education through interactive processes among subjects, the collectivity and institutions, actions in the reality to promote changes, to mobilize ways, to agree with processes and to foment the formation of knowledge and inventions ${ }^{(18)}$.

The permanent education, which covers the significant learning proposes that the transformation of the professional practices, must be based on the critical reflection regarding the real practices of health professionals in action with and in the health services ${ }^{(19)}$. It is a way for emancipation and autonomy of health professionals, once during the 
meeting between the professional education and the world of work is where learning and the teaching are incorporated to the daily activities ${ }^{(19)}$. So, the transformation of the professional practices and the organization of the work itself should be instigated, having as reference the needs of health of the subjects, of sectorial management and of the social control in health.

The inter-institutional articulations should be incentivated and supported inside the Health Unified System, so that the permanent education in health is instituted in the values of planning, management and mediation. So, the political guidelines of ordination of the education in health will be made in an aggregating manner directed by the public interests in tune with the local regional singularities ${ }^{(18)}$. The integration and articulation on of the several department such as Social Assistance, Education, Health, Environment, Infrastructure, among others are indispensable in order to supply the real needs of health of the population to be worked and discussed, in order to clarify joint and coordinating actions to overcome the obstacles in health care, which are today, the highest challenge.

\section{Final Considerations}

The Previous Health Conference revealed, at the same time, the growing plurality of the society and its interests and the distance among the managers on one hand, and on the other hand the organs of social participation. Plurality was present both in the composition of the delegates as well as in the diversity and in the large number of proposals sent, totalizing 50. The distance was around a small number of matters such as, for example, when presenting the proposal of the need of inter-sectorial questions among the different departments to optimize the results in health, this was done in a hurried manner, without reflection and without wider preparation for the debate.

The growing plurality and the existence of an expressive number of specific proposals can, at times, displease many managers but it is necessary to recognize that, after all, society is each time more plural and the needs of health are, actually, diverse, specific and are formed and present in the process health-disease. It is inevitable that, as society becomes more complex and organized, new needs are recognized and brought for discussion and expression. One should go further; maybe this is the only way that a social policy of importance of the Health Unified System becomes in fact universal, assisting all the citizens in an equitable manner.

The distance among the management and the organs of social participation is a real and serious problem but it cannot be solved in an impulsive way. Its continuity and aggravation jeopardize the Health Unified System and the effectiveness of its actions and services. The problem must be recognized and confronted through a change of posture, qualified listening, promotion of the dialogue in the difference according and around the new democratic methods of organization. Otherwise the Pre-Conferences and the Health Conferences have the real risk to present reduced effect or even null in terms of the direction of the health policy. The true challenge is to reach a model of organization and functioning of the conferences in which the social participation promotes and sustains the permanent renovation of the public relevance of health in consonance with the strengthening of the public system of health in Brazil.

In order to build democratic venues of debates, the management counsels must make visible that the social subjects with different interests dialogue on conceptions and projects and learn to find consensus favoring collective interests.

It is discovered that the communitarian participation should be wider than the formal venues of social control in order to enhance alliances with popular movements, with the non-governmental organizations, with the several departments and with the public organs of control. So, the health counsels can perform their role and implement the bases of 
support of a new relation of expressive strength of the population with the State. It is primordial to promote this change of attitude not only by members of the counsels, but by the users, managers and health professionals. It is utterly necessary to propose strategies facing empowerment and liberation of all the social actors who are interlinked in the process of construction and consolidation of the Health Unified System.

\section{Collaborations}

Lopes-Júnior LC participated in the conception, analysis, interpretation of the data and final approval of the version to be published. Pereira MJB participated in the interpretation of the data, writing of the article and final approval of the version to be published. Mishima SM participated in the conception, analysis, interpretation of the data and final approval of the version to be published.

\section{References}

1. Conselho Nacional de Secretários de Saúde CONASS. Coleção para entender a gestão do SUS. 0 processo de implantação do SUS. In: Conselho Nacional de Secretários de Saúde. Sistema Único de Saúde. Brasília: CONASS; 2011. p. 52-118.

2. Teixeira ML, Vianna W, Cavalcanti ML, Cabral MP. Participação em saúde: do que estamos falando? Sociologias. 2009; 11(21):218-51.

3. Brasil. Constituição da República Federativa do Brasil de 05 de outubro de 1988. Diário Oficial da República Federativa do Brasil. Brasília, DF: Senado; 1988.

4. Bordenave JED. 0 que é participação. 8 ${ }^{\underline{a}}$ ed. São Paulo: Brasiliense; 2002.

5. Côrtes SMV. Conselhos e conferencias de saúde: papel institucional e mudança nas relações entre Estado e sociedade. In: Fleury S, Lobato LVC. Participação, democracia e saúde. Rio de Janeiro: CEBES; 2009. p.102-28.

6. Cristo SCA. Controle social em saúde: o caso do Pará. Serv Soc Soc. 2012; (109):93-111.
7. Fleury S. Brazil's health-care reform: social movements and civil society. Lancet. 2011; 377(9779):1724-25.

8. Lanzoni GMM, Lino MM, Schveitzer MC, Albuquerque GL. Direitos dos usuários da saúde: estratégias para empoderar agentes comunitários de saúde e comunidade. Rev Rene. 2009; 10(4):145-54.

9. Secretaria Municipal da Saúde de Ribeirão Preto. Divisão de Planejamento em Saúde. 8a Conferência Municipal de Saúde, 2011 [Internet] 2011 [citado 2013 jun 13. Disponível em: http:// www.ribeiraopreto.sp.gov.br/ssaude/conselho/ i16indice4.php.

10. Paim J, Travassos C, Almeida C, Bahia L, Macinko J. The Brazilian health system: history, advances and challenges. Lancet. 2011; 377(9779):177997.

11. Victora CG, Barreto ML, Leal MC, Monteiro CA, Schmidt MI, Paim J, et al. Health conditions and health-policy innovations in Brazil: the way forward. Lancet. 2011; 377(9782):90-102.

12. Escorel S. Conselhos de Saúde: entre a inovação e a reprodução da cultura política. Saúde Debate. 2008; (43):23-8.

13. Batagello R, Benevides L, Portillo JAC. Conselhos de Saúde: controle social e moralidade. Saúde Soc. 2011; 20(3):625-34.

14. World Health Organization (WHO). The World Health Report. Primary Health Care - Now More Than Ever. Genebra: WHO; 2008.

15. Kleba ME, Matielo A, Comerlatto D, Renk E, Colliselli L. O papel dos conselhos gestores de políticas públicas: um debate a partir das práticas em Conselhos Municipais de Chapecó (SC). Ciênc Saúde Colet. 2010; 15(3):793-802.

16. Bispo Júnior JP, Gerschman S. Potencial participativo e função deliberativa: um debate sobre a ampliação da democracia por meio dos conselhos de saúde. Ciênc Saúde Coletiva. 2013;18(1):7-16.

17. Cotta RMM, Martins PC, Batista RS, Franceschinni SCC, Piore SE, Mendes FF. O controle social em cena: refletindo sobre a participação popular no contexto dos Conselhos de Saúde. Rev Saúde Coletiva. 2011; 21(3):1121-37.

18. Saldanha OMFL, Pereira ALB, Medeiros CRG, 
Dhein G, Koetz LCE, Schwertner SF, Cecim RB. Clínica-escola: apoio institucional inovador às práticas de gestão e atenção na saúde como parte da integração ensino-serviço. Interface [periódico na Internet]. 2014 [citado 2013 jun. 13]. Disponível em: http://www.scielo.
br/scielo.php?script=sci_arttext\&pid=S141432832014005030446\&lng=en

19. Jesus MCP, Figueiredo MAG, Santos SMR, Amaral AMM, Rocha LO, Thiollent MJM. Permanent education in nursing in a university hospital. Rev Esc Enferm USP. 2011; 45(5):1229-36. 